\title{
Socio-spatial inequality and the impact of Covid-19 on the population of Rio de Janeiro: analyses and reflections
}

Desigualdade socioespacial e o impacto da Covid-19 na população do Rio de Janeiro: análises e reflexões

Daniel de Albuquerque Ribeiro [I] Aruan Francisco Diogo Braga [II] Lino Teixeira [III]

\begin{abstract}
Severe Acute Respiratory Syndrome (SARS-COV-2) is a disease caused by the new coronavirus, whose dissemination across the world has caused the Covid-19 pandemic. This article is based on the spatialization of governmental data about the city of Rio de Janeiro, combined with interviews and other types of information. It starts from a theoretical perspective that considers the action of different agents in the contribution of socio-spatial processes. The writing of the article was grounded in the bulletin "Mapa Social do Corona" (Social Map of the Coronavirus), issued by Observatório de Favelas between June and August 2020 with the collaboration of an interdisciplinary team, in partnership with different institutions and professionals. It shows that socio-spatial inequality has contributed to a higher lethality rate in low-income neighborhoods.
\end{abstract}

Keywords: Covid-19; socio-spatial processes; Rio de Janeiro.

\section{Resumo}

A Síndrome Respiratória Aguda Grave é uma doença causada pelo novo coronavírus, cuja disseminação em escala mundial causou a pandemia da Covid-19. Este artigo tem por base a espacialização de dados governamentais relativos à capital fluminense, combinada com entrevistas e outros tipos de informações. Parte de uma perspectiva teórica que considera a ação de diferentes agentes na contribuição dos processos socioespaciais. A elaboração deste artigo teve por base o boletim Mapa Social do Corona, realizado pelo Observatório de Favelas, entre junho e agosto de 2020, que contou com a colaboração de uma equipe interdisciplinar em parceria com diferentes instituições e profissionais. Evidenciou-se como a desigualdade socioespacial contribuiu para uma taxa maior de letalidade nos bairros populares.

Palavras-chave: Covid-19; processos socioespaciais; Rio de Janeiro. 


\section{Introduction}

Severe Acute Respiratory Syndrome 2 (Sars(oV-2) is a disease caused by Coronavirus whose worldwide spread has caused the Covid-19 Pandemic. Tracing a brief chronology regarding the disease, we can observe that the first cases were registered in late 2019 in China and in January 2020, it was declared as a public health emergency of international importance (Opas, 2020). According to the office of the Pan American Health Organization (PAHO) and the World Health Organization (WHO) in Brazil (Opas, 2020), on March 11, Covid-19 was characterized as a pandemic due to its spread around the world.

Until September 11, 2020, more than 28 million cases have been confirmed worldwide, 4,335,066 in Brazil. On September 15, 2020, the state government of Rio de Janeiro published a bulletin declaring that there were 244,418 cases in the state, of which 17,180 resulted in death. Of this number, 96,051 cases were recorded in the capital of Rio de Janeiro and 10,233 died. (IPP, 2020)

This article aims to report some of the findings obtained from a survey ${ }^{1}$ that began in June 2020 and ended in August of the same year. It also provides updated information from a data survey in late July. In addition, this article brings together an integrated analysis of the findings that were obtained and published in installments in bulletins in the months of June and July 2020 (OF, 2020). In this one, we tried to understand a set of elements that implied the dissemination of Covid-19 in the city of Rio de Janeiro and the impact on its vulnerable population. For this, the interactions at multiple scales and the differentiation of the impact between the rich and peripheral areas of the city were taken into account.

For this, two methods of procedure were adopted: historical and comparative, with the following methodological procedures: analysis of government data related to Covid-19 and spatialization of these data on maps; map analysis; in-depth interviews to understand the realities hidden by the data; interscalar analysis of the information; analysis of the temporal sequence of dissemination of cases of Covid-19 in the state of Rio de Janeiro.

In the second section of this article, a brief conceptual contextualization, which supported this work, will be traced. In the third section, the Human Development Index - HDI, and its distribution in the neighborhoods of the state capital will be analyzed. In the fourth section, the number of cases per neighborhood will be analyzed, together with the number of deaths and lethality rates. In the fifth section, the distribution of health equipments in the city of Rio de Janeiro and the issues inherent to its access will be observed. In the sixth section, the study on a regional scale will be addressed as well as the interaction of the capital of Rio de Janeiro on different scales ${ }^{2}$ and the possible impact of this on the spread of the disease in the state.

\section{Conceptual foundation}

Space and time are two inseparable elements when the object of study is a social phenomenon. Thus, the city as a form, 
brings together the elements that intertwine the socio-spatial processes. In the book $A$ Natureza do Espaço (Nature of Space), Milton Santos (2008) emphasizes the importance of observing technical objects, considering technique as the link between time and space. Socio-spatial processes will result in different spatial forms, as explained by Corrêa (2005). According to Vasconcelos (2013), socio-spatial processes can be categorized according to three notions: those linked to spaces; those linked mainly to individuals and; those linked to individuals and spaces.

Based on this principle, each part of the city presents shapes resulting from different processes, such as centralization, dispersion, segregation, gentrification, fragmentation, among others. In capitalist cities, the processes that unfold internally are often products of larger ones such as Globalization, as pointed out by Ribeiro (2018) in his thesis on migration and socio-spatial processes.

Based on this premise, it is possible to look back at the municipality of Rio de Janeiro and observe the different processes of the city that generate different impacts on Covid-19 dissemiination in its territories.

The number of elements that involve the process of dissemination and mitigation of Covid-19 in Brazil and specifically in Rio de Janeiro makes its study complex. Morin warns that one of the main guiding points of complexity revolves around incompleteness. "In fact, inspiration for complexity tends towards multidimensional knowledge. It doesn't want to give all the information about a studied phenomenon, but to respect its different dimensions. " (Morin, 1995, p.177, own translation). Based on this assumption, it is understood that the contribution of this study lies in what it can offer in addition to the many researches that are already being developed on the disease. In this specific case, with a focus on the socio-spatial perspective and with transdisciplinary analyzes.

The theoretical look of this article came from the studies of socio-spatial agents. The first study found on the subject is that of Wiliam Form (1954). In Brazil, it was the geographer of IBGE (Brazilian Institute of Geography and Statistcs) called Bahiana (1978) who first approached the subject. The authors who worked with the theme ended up bringing up the complexity of urban studies.

As an example, Corrêa (2005: 2013) brings important contributions to his studies on urban space considering that it is produced by the combination and correlation of forces of different agents. Vasconcelos (1997) amplifies the debate temporally, explaining that different temporalities produce different agents (1997) and also typologically (2013).

Ribeiro (2011) points out that the interaction of these agents also needs to be considered at different scales, and that the same agent may have antagonistic positions in their particularities when facing an action. Thus, the State as an agent can exercise different actions within its particularities (federal government, states and municipalities); also the population, although considered as an agent, has different sectors that need to be considered particularly. Ribeiro concludes that the study of sociospatial agents and processes is possible from the paradigm complexity.

Based on these assumptions, it is possible to point out how the actions of the different agents contributed to the dissemination and mitigation of Pandemic 
in the municipality of Rio de Janeiro. The State in its different instances had conflitant positions. From the negationist stance of the federal government, through corruption scandals of the state government of Rio de Janeiro to the recent scrapping of the public health system, especially the Family Health Program Strategy in municipal level.

Even the Churches presented different positions with some segments encouraging the faithful to continue to attend the temples and others respecting the norms of isolation. Likewise, the economic agents who had the know-how and capital were able to seize the moment and profit, however, a portion of the entrepreneurs with their establishments closed and with no prospect of return, began to pressure the State so that measures were adopted aiming at the returning of commercial activities

Brazilian society relied on all kinds of possible reactions, ranging from skepticism in the face of the disease and to protests against isolation measures to groups that had the material conditions to isolate themselves in their homes. In addition, the cases that, although some found the need for isollation, did not have the material conditions to do so, being forced to break the isollation to work. Amidst this diversity of behaviors and from specific territories of the city, the favelas and peripheries developed a series of solidarity actions, which allowed, to a certain degree to mitigate the devastating effects of Pandemic in the most needy population of Rio of Janeiro.

The actions spearheaded many times by the population of the popular areas point out what Santos (2003) indicates by stating that only the periphery can promote change in the system that oppresses it.
Far from being conclusive, but taking as a starting point, this study indicates that, through totalizing oppression, it is possible to think of alternatives, as Harvey (2004) sees, not accepting what is established by the system and understanding that utopia can be a reality as long as there is non-conformity with inequality.

For this article, three main agents will be listed: the State and the impact of its actions on the population of Rio; economic agents and, in this case more specifically, those who have and offer private health equipment; the population, for obvious reasons, since it is the most affected in every way by the pandemic. Based on this assumption, it is possible to start the analysis considering the spatialization of this population in the state capital from the study of the Human Development Index - HDI.

\section{Human Development Index}

A first point to consider in relation to the dissemination of Covid-19 in the municipality of Rio de Janeiro refers to the protection and vulnerability of the population. This implies the premise that even though the virus does not distinguish who will be infected, its effect can be more devastating depending on the social group it reaches.

In the first moment of the research (OF, 2020d), the Covid-19 Protection Index was used, developed by the Ação Covid (Covid Action) research group (2020), which considered the $\mathrm{HDI}$, the demographic density and the lethality rate as basic criteria. However, for this article, it is understood that the isolated analysis of the HDI may offer 
elements that allow a better understanding of the social inequality spatially structured in Rio de Janeiro. After, we evaluate the factors that influenced the dissemination of Covid-19 as well as its impact on the population of Rio de Janeiro, both in gross numbers of deaths and in relative terms, such as the lethality rate.

Thus, with regard to protection or vulnerability, it is possible to list a set of factors, one of which is biological as a derivation of the socioeconomic aspects of each individual. The possibility of greater immunity implies a differentiation in the impact of the virus on infected people. In addition, after contagion, the structural conditions for dealing with the disease can be differentiated. This ranges from access to private health ensurance that can guarantee a hospital bed to no public access to treatment at all.

We have to enphasize the fundamental role that Sistema Único de Saúde (SUS), the National Public Health System, has been playing during the pandemic, resisting the absence of public policies at the national level and the weakening it has suffered in recent years. Throughout the Mapa Social do Corona Bulletin, we were able to approach some public health professionals that have been working in Rio's favelas, to better understand their perspectives. It is evident that, despite successive attempts to scrap structure and working conditions, SUS was able to avoid even more dramatic scenarios for the popular strata.

Another factor added to that is the possibilities of keeping oneself in safe and healthy conditions during the period of isolation. The middle and upper class population have means to reduce exposure to the disease, due to the possibility of working from home, using private vehicles and having a lower residential demographic density and greater access to private leisure facilities. The low-income people, on the other hand, ends up exposing themselves more to contagion due to adverse conditions such as the need to go to work, to guarantee their livelihood, having to use public transportation. Additionally, conditions in the residence itself can make isolation difficult, which means that the risk of contagion is greater, even if one tries to take precautions in the best way.

In addition to all these aspects, many others can be added, such as the issue of basic sanitation, which implies access to essential elements of hygiene, resulting in another obstacle in protecting from the disease.

Another relationship between agents is configured in the provision of health services. On the one hand, there is a greater presence of the State in rich and central areas, thus, offering essential services, while in the peripheral areas, the proportion of supply of these services is lower. Added to this is the fact that the economic agents that offer health services will offer their services in the richest and most central areas of the city, where they will find the consuming public. Thus, a logic of social inequality is revealed, denounced in the quantitative and qualitative concentration of services in the urban space as well as their access.

The Human Development Index - HDI map (map 01) spatializes the information, showing a logic that was present throughout the study (OF, 2020). The analysis considers the five Planning Areas (APs) of Rio de Janeiro, comparing the internal reality of the municipality and considering the lowest indexes as very low and the highest ones as very high - note that AP 01 (Center) 
has a medium and high index in some neighborhoods. The South Zone (AP 03) has a high and very high waterfront area, which extends all along the coast to AP 04 (West), in neighborhoods such as Barra da Tijuca and Recreio dos Bandeirantes, being Rocinha an exception in the middle of the spread of noble areas of the municipality.
At the same time, in the innermost part of AP 03 and AP 04, there is the presence of some of the neighborhoods with the lowest index. This, in turn, contrasts with the North Zone, which has a greater heterogeneity of cases, with neighborhoods with $\mathrm{HDI}$ ranging from the lowest to the highest rates, but with a predominance of neighborhoods with a low HDI.

Map 1 - Human Development Index in the Municipality of Rio de Janeiro

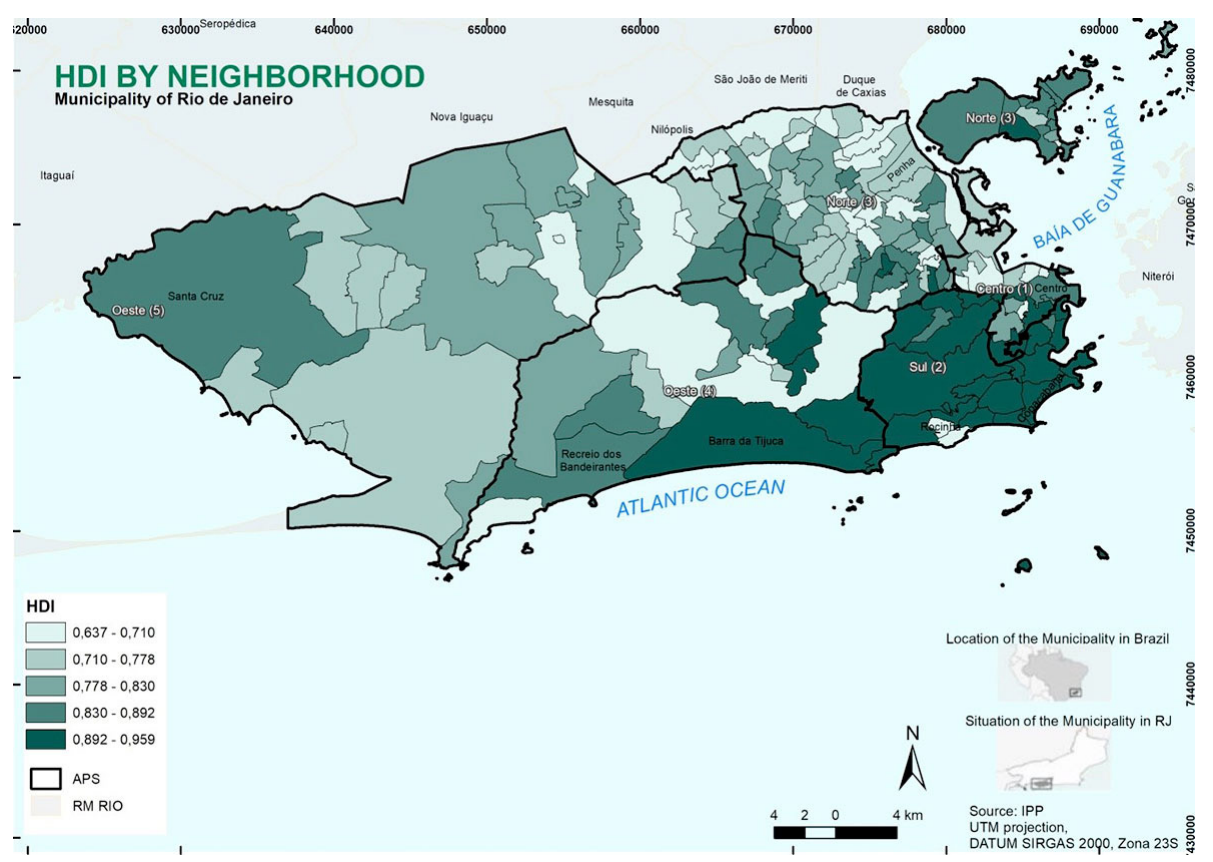

Source: IBGE (2020); IPP (2020). Prepared by the authors.

Cartographic base: IBGE (2020) 
Finally, AP 5, which concentrates the largest portion of peripheral neighborhoods in Rio de Janeiro, despite having a low HDI, compared to other parts of the municipality, does not have the worst rates in all neighborhoods, but in a part of them. As we can see he worst rates are in the peripheries and slums.

Considering the analyzes traced so far, we observe that while there is a contiguous zone with a high HDI that extends from the Center (AP 1), through almost the entire South Zone (AP 2), reaching to a considerable part of the South of AP 4, as it advances to AP 5, the HDI decreases and, thereby, increases the vulnerability. In other words, the richest part has, for the most part, better conditions of protection against the effect of the Pandemic, while the rest of the city has these chances reduced, with some exceptions.

The spatialization of this index is a starting point, which helps to understand the socioeconomic distribution of the population of Rio de Janeiro, but that, by itself, is not sufficient to explain the process of dissemination and impact of Covid-19 in the capital of Rio de Janeiro. Therefore, it is important to analyze other elements, starting with the Lethality Rate.

\section{Deaths and lethality in Rio de Janeiro}

Considering the data made available by DATASUS (2020), it was possible to spatialize the number of contaminated and deaths by neighborhood and, thus, have a dimension of the impact of COVID-19 in the different neighborhoods of Rio de Janeiro (map 02). This information demonstrates how social inequality was expressed with the pandemic. While the first map indicates that the virus does not distinguish between contamination, the second shows that its lethality is higher in populations with less economic power. This rate, built from the number of contaminated and deaths and spatialized on the third map, makes it clear that its greatest impact was felt in the peripheral neighborhoods of Rio de Janeiro.

It is important to highlight that these data do not concern the totality of cases, since the underreporting of occurrences and, consequently, of deaths, may have contributed to camouflage an even greater damage that the country and the capital of Rio de Janeiro have suffered. This damage is due to the negligence in the different spheres of government in the face of the pandemic announced in early March 2020.

Considering AP 3 and the south of AP 4, where the same neighborhoods are found with high HDI, it is visible that most of them had a lower lethality rate, even though, in some cases, they had an intermediate and even high contagion index as in the cases of Barra da Tijuca in the south of AP 4 and Copacabana in AP 3.

On the other hand, there is a high lethality rate in AP 2 indicating that, although the number of deaths in each neighborhood was proportionally lower than that of some neighborhoods in the richest area of the city. The proportional impact considering the number infected was much higher. This reveals the aspects already mentioned in 
Map 2 - Contagion, deaths and lethality until 7/15/2020 in Rio de Janeiro
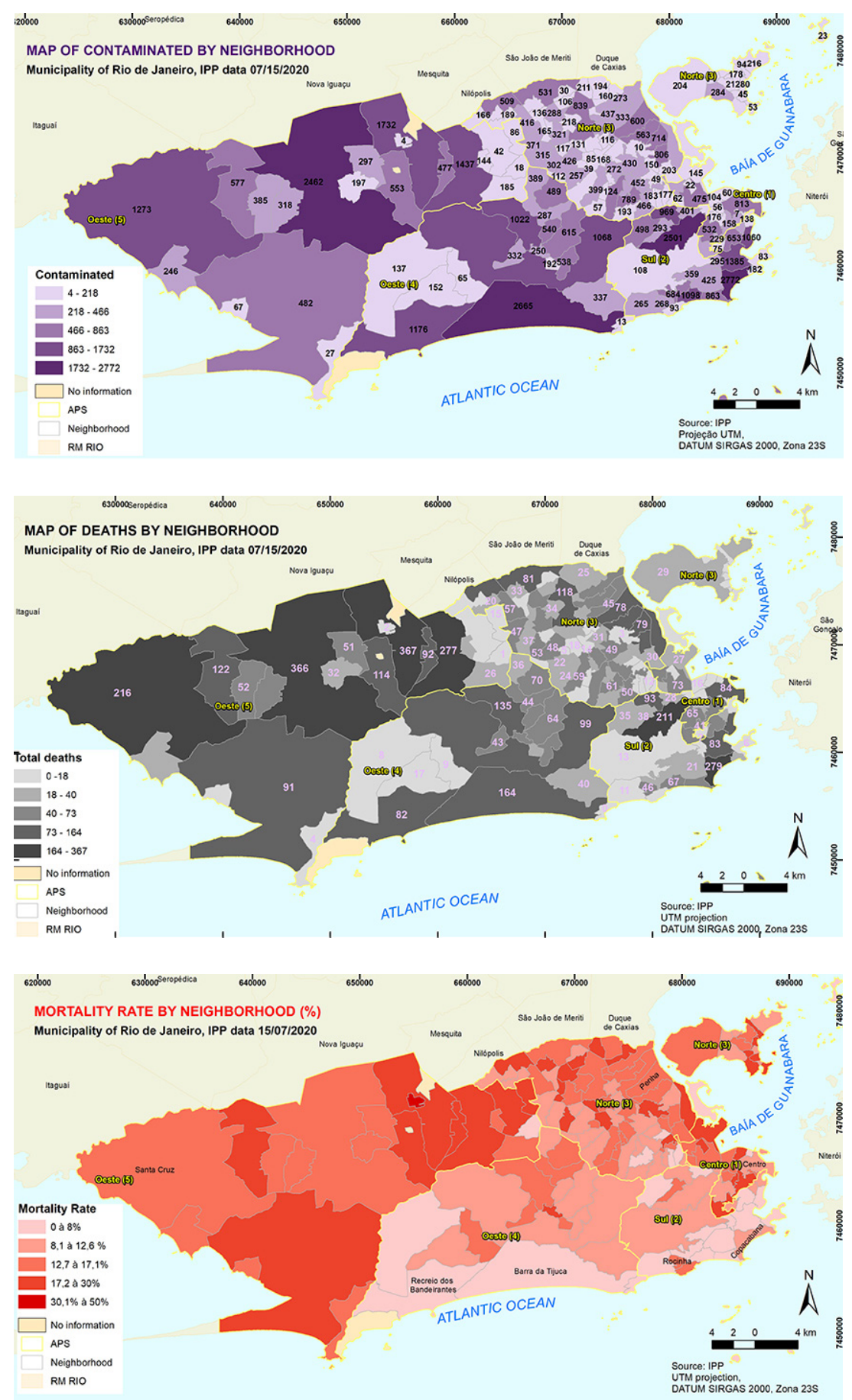

Source: IBGE (2020); IPP (2020). Prepared by the authors.

Cartographic base: IBGE (2020) 
the third section of this article regarding the variation of the impact of the pandemic according to the different socioeconomic conditions of the population.

Another element to be analyzed is that four neighborhoods in AP 5 (West) had, in the beginning of July 2020, a number of deaths in excess of 140 individuals, concentrated in peripheral area of Rio the neighborhoods. This ended up being camouflaged in the first analysis published in the bulletins (OF, 2020), due to the fact that the sum was considered with the other neighborhoods that had a lower number of deaths. Still on AP 5, the most serious case is in Santa Cruz, which, despite an intermediate rate of contagion, presented one of the highest numbers of deaths.

One of the analysis carried out, that was suppressed in the form of maps, but that can be reported, concerns the internal vectors of contagion in the municipality of Rio de Janeiro. The first recorded cases were in the upscale neighborhoods. Thus, the upper middle class of the municipality imported the virus into the territory of Rio de Janeiro and contaminated the population of the peripheral areas, which provide services in the central neighborhoods and in the South zone. Thus, the number of contaminated people that, in the first months, was higher in APs 3, 2 and South of 4, was evened up to the month of July 2020, when the data were analyzed.

Having analyzed the HDI and lethality of COVID-19 in the population of Rio, it is now necessary to observe how the performance of the State as well as the economic agents working in the health field takes place in the territory of the capital of Rio de Janeiro and, thus, identify the elements that deepen inequality expressed in unequal access to health.

\section{Access to health in Rio de Janeiro}

Access to health is not limited to health equipment itself, but to a set of elements that will allow a healthy life and greater protection against all types of illness. It is not new that prevention is much more effective than treatment. However, prevention is built around a set of physical, vital, mental and emotional aspects.

With regard to physical elements, access to basic sanitation, regular garbage collection, adequate work and housing conditions, add up so that the body is resistant to diseases. Healthy eating and the possibility of adequate rest are essential for the body to preserve its vitality. Similarly, psycho-emotional conditions add up to countless factors that can drain a person's energy making her more vulnerable. These are some aspects that can make difference in terms of protection and recovery of those with symptoms of the disease.

However, many of these issues could be worked on, by the population's access to preventive health units with adequate followup to citizens. In addition, after the disease sets in, access to health facilities qualified for this service is essential for recovery. Considering these aspects as a basis, a map of access to health in the municipality of Rio de Janeiro was elaborated (Map 3). 
This analysis, published in the fifth edition of the Mapa Social do Corona bulletin (OF, 2020), was prepared by the Observatório de Favelas team in partnership with the team from the Postgraduate Program in Urbanism (Prourb). For this, the study of opportunities for accessing health carried out by Ipea (2020) was considered besides the National Registry of health establishments (CNES, 2020). In the crossing of this information, it was possible to observe how the rarefaction of health equipment in part of the West Zone may indicate one of the aspects that hinders its access.

In addition to the classification of health equipment as hospitals and others, and as private or public, the map considered the Ipea studies, which defined the time and distance that a person would take to reach a hospital bed - measured within $5 \mathrm{~km}$, and basic care equipment aimed at Covid-19 cases - measured in up to 30 minutes on foot (see map legend).

Map 3 - Health access map in the city of Rio de Janeiro

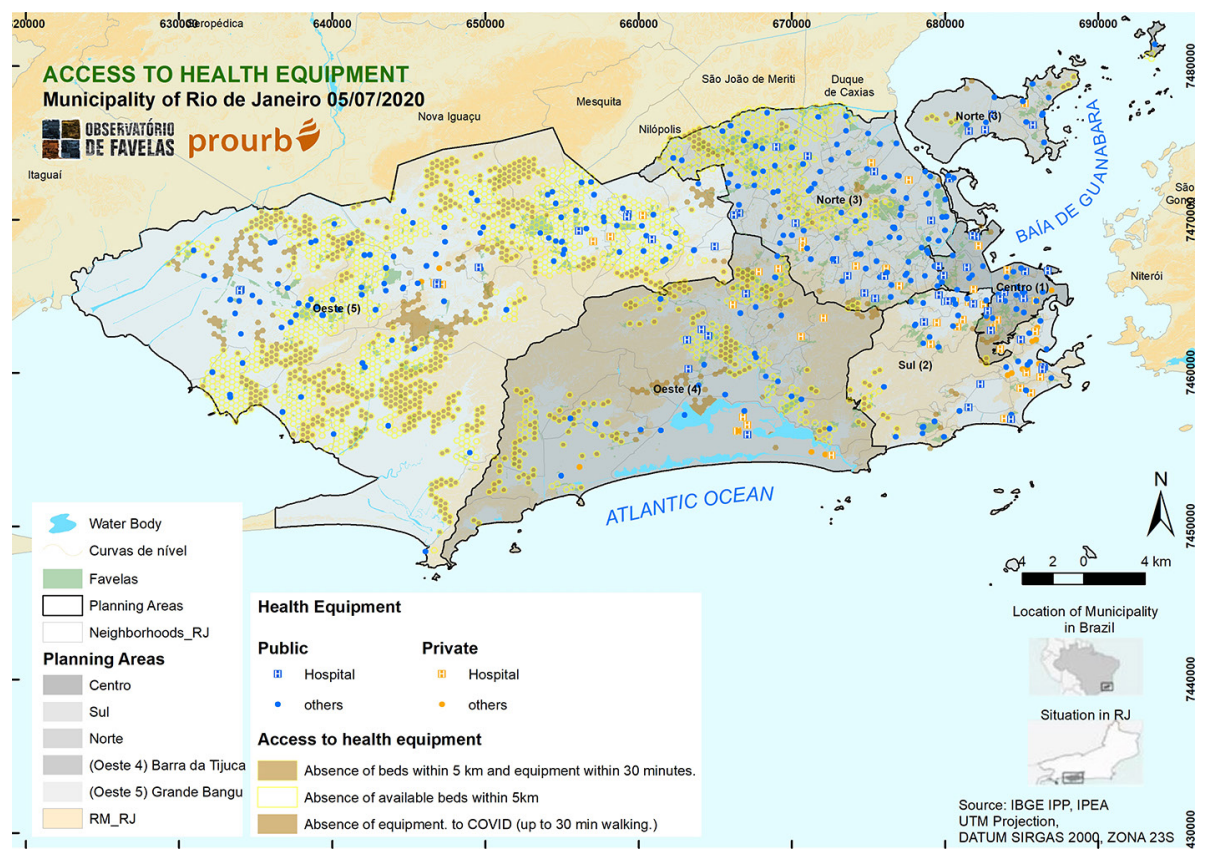

Source: IBGE (2020); IPP (2020); IPEA (2020). Prepared by the authors.

Cartographic base: IBGE (2020) 
This shows the impediments to access to health care in the West Zone; even though it has basic care units, most of which are offered by the Municipality, they are not satisfactory to meet the needs of the population of AP 4 and especially AP 5.

The higher density of health equipment in AP 1 (Centro) is explained by the historical process of concentration of urban equipment in downtown. Corrêa (2005) explains that this phenomenon is called the centralization process. At the same time, it is clear that in the upscale area, although not counting the same amount as in downtown, access is guaranteed mainly by the possibility of this wealthy population to access private means and to move to more distant areas, including in downtown.

However, in addition to the factors previously explained, what would explain the high lethality rate in Ap 2 - North, if it has a greater amount of health equipment? In this case, the demographic density, associated with social indicators, such as the HDI, in conjunction with the interviews ${ }^{3}$ conducted during the survey of the Social Map of Corona (OF, 2020), brought answers.

Despite the fact that AP 2 has the second largest distribution of health equipment in quantity, its presence does not mean that it offers enough hospital beds, medical equipment and health professionals to serve the local populations. This was evidenced when deepening in the reports of health professionals who denounced the precarious conditions with which they need to act in their work routine. This situation got worse with the Pandemic. The overloading on health equipment, in turn, needs to be understood in an analysis that goes beyond the territorial limits of Rio de Janeiro.

\section{Inter-scale analysis of Covid-19 in Rio de Janeiro}

When working with the game of geographic scales in order to understand the process of expansion and impact of Covid-19 in the capital of Rio de Janeiro, three parameters were established. The first one analyzes the regional relationship of the municipality of Rio de Janeiro, with the State of Rio. The second one considers a keynote of the Covid-19 pandemic, which is the overloading on health equipment and, for this, a broader analysis was carried out, considering the cases of Severe Acute Respiratory Syndrome that were hospitalized. The third parameter consists of a temporal analysis of the evolution of hospitalizations, which revealed how the disastrous policies adopted by the State contributed to overcoming the mark of 100,000 deaths throughout Brazil, and more than 15,000 in the State of Rio de Janeiro.

The analysis of a municipality of the size of Rio de Janeiro needs an effort that aims at understanding the scale of the place and other broader ones, such as the Metropolitan Region, National and the world scale. Within the scope of the place, it is important to highlight what the data does not reveal, once they tend to generalize the particularities, through spatial averages. On the other hand, when it is limited to what is in the territorial limits of the Municipality, the visualization of the influence of external connections to it is lost, either with its surroundings or with broader scales.

According to IBGE (2007), Rio de Janeiro is a national metropolis. Thus, this city polarizes and exerts influence throughout 
the Brazilian territory. For instance, within the Brazilian territory, there are services that can only be found in some cities in the country, such as Rio de Janeiro, or that may be cheaper in this metropolis. An example is the airport. Some international flights are only possible to be made, departing or arriving from a small number of Brazilian airports. Galeão airport is one of those. In addition, when flights go to another city, they often stopover in Rio de Janeiro, São Paulo or Brasília (although, in some cases, the journey is made longer).

Another example is labor. Historically, concentrating a considerable portion of investments in the country, the southeast brazilian region, of which Rio de Janeiro is part, ends up retaining a greater supply of labor. This is a determining factor for this pole to attract migration. In the particular case of Rio, these migrations often occur on a pendulum or seasonal basis, with people working and studying in the capital of Rio de Janeiro and residing in other municipalities and even in other states.

Although there are an infinite number of issues to be balanced, the analysis of these three factors, population flow, work and concentration of services, already makes it possible to deepen the understanding of the polarization exercised by the capital of Rio de Janeiro. Considering this, the first reflections will be drawn based on the Map of Health equipment (map 03), by comparing it with the Map of the Origin of Hospitalized Patients (SARS) that were hospitalized in the municipality of Rio de Janeiro (Map 4).

One of the assumptions already made in relation to COVID-19 is the overload of health services. For this reason, a more complete analysis would require a complex set of factors, such as the demand for professionals (human resources) and health equipment (physical and structural resources). As an example, with the overcrowding of the hospital beds, patients began to be referred to other municipalities. In addition, due to the inability to meet all patient demand, at some point, some units in Rio de Janeiro had to choose who would receive treatment or be sent home.

When analyzing the access to health, it is understood that it is not only the distribution of hospitals, and other types of units in the municipality, that will ensure that this access occurs in a balanced way. This is due to the demographic demand of a place, as well as the conditions of access, either due to the way of commuting or due to the possibility of a person to access hospitals and private clinics. However, this impact is amplified, when taking into account that many hospitalizations in the city of Rio de Janeiro originated from patients from other locations in the state. The cities that met the subregional demands ${ }^{4}$ are also not being exposed here.

If, on the one hand, the peripheral and favela population needs to wait for the provision of a public service that is already overloaded with demands, this situation is aggravated by the demand from other municipalities due to the increase in patients who need beds in hospitals. It is also noteworthy that these data are not considering people from other states or foreigners. It is also important to note that the previously mentioned underreporting camouflaged a worse reality than the one already stamped in the data. 
Map 4 - Patients hospitalized in Rio de Janeiro with origins in other cities - 2020

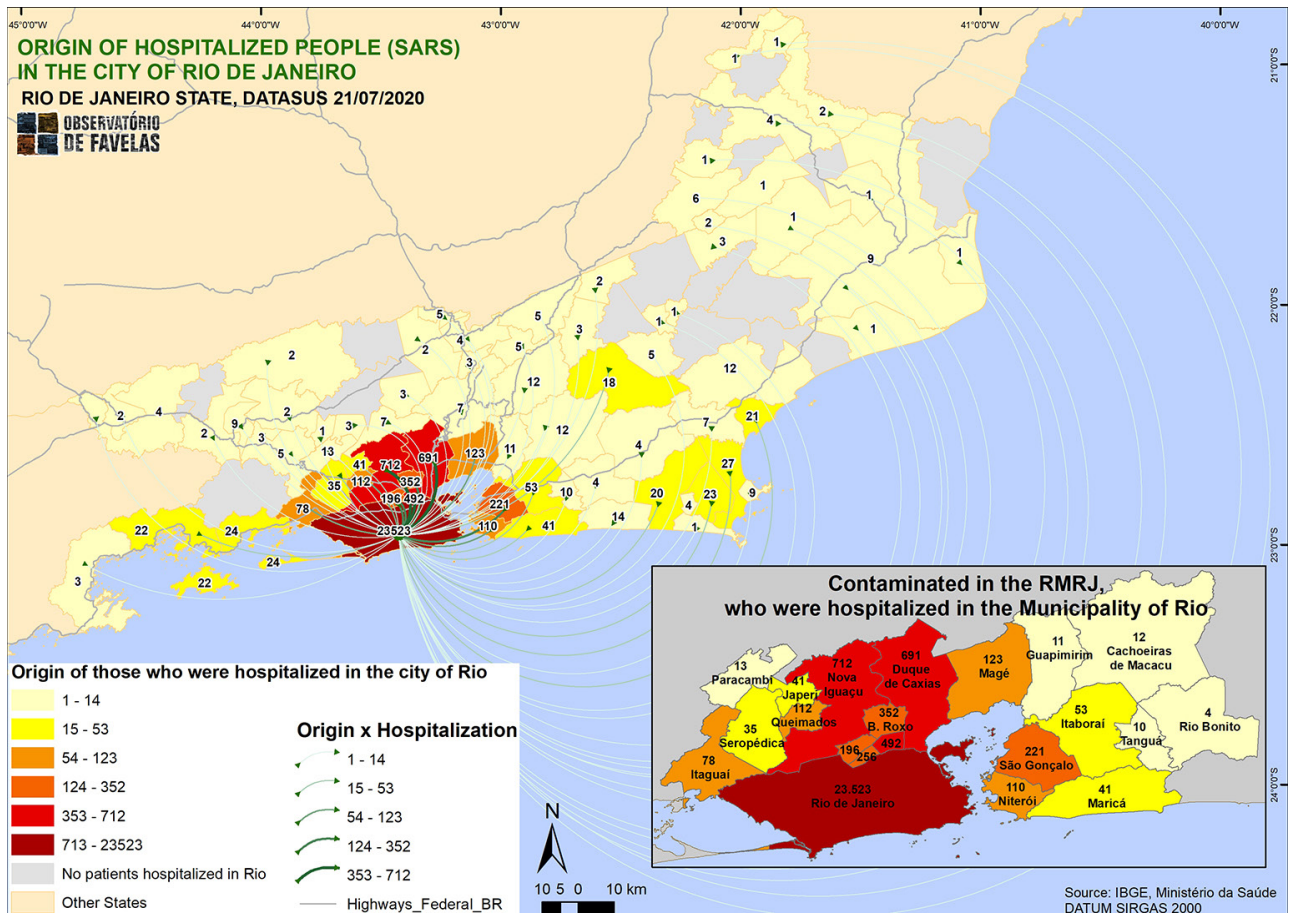

Source: Datasus (2020), accessed on: 07/21/2020. Prepared by the authors.

Cartographic base: IBGE (2020).

One of the most important elements that need to be considered in the expansion study of Covid-19, is its spatial character. If this had been observed by the Federal Government at the time when the international alert regarding the danger of Covid was decreed, still in January 2020, or at least in March 2020, when Pandemic was declared, its impact could have been reduced. To develop the argument, it will be necessary to use the cartographic resource and observe the expansion vector of Covid-19 in the state of Rio de Janeiro.
If on the one hand, airflow played a decisive role in the importation of Covid-19 to the territory of Rio de Janeiro, the temporal sequence of contagion per month indicates the role that road flows played in the spread of the virus throughout the State of Rio of Janeiro. To better understand this statement, we must observe the sequence of maps. The indexes observed in January and February comprise key parts to understand the four subsequent months (Figure 1). 
Firstly, it is necessary to emphasize that the information collected registered the onset of symptoms of Severe Acute Respiratory Syndrome (Sars); therefore, the analysis of this temporal sequence occurs in relation to all cases of Sars and not only Covid-19. However, when observing January and February, it is detected that, proportionally, the number of people who presented some typical symptoms of SARS, remained similar, to some extent, except for the capital of Rio de Janeiro, whose records have already risen considerably compared to the previous month. Here, the impact of Carnival, as an element for the dissemination of respiratory diseases, is highlighted.

In April, the state reached the peak of contagions with 110,000 infected people only in the capital of Rio de Janeiro, with the highest number of contagions in the entire state. However, although May and June have shown a reduction in the number of notifications from infected people, it is noteworthy that, depending on the patient's condition, hospitalizations can last from days to months. Therefore, together with the map of symptom onset by month, it is possible to use another analysis considering the sum of cases per month and, thus, if the overloading on the health system is dimensioned, once, with each new entry into the hospitals, it is added some of which were previously established (Figure 2).

In March, there has already been a dramatic increase in cases of hospitalized patients in Grande Rio, and the registration of cases in practically all Rio de Janeiro. This would be a decisive moment to change the course of the Pandemic in the country. ${ }^{5}$ The consequence of this is evident in the following three months, with the increase in cases and the chain impact, spreading throughout the country, overloading the health system and affecting even more the socioeconomically vulnerable population, once its conditions of dealing isolation aspects are precarious.

For a better understanding, we emphasize that, while the first sequence of maps (Figure 1) had the data spatialized without adding cases from one month before the subsequent one, in the second sequence of maps (Figure 2), the sum of the six months was totaled. For example: the municipality of Rio de Janeiro registered 20,656 cases in June 2020 , but the sum of the six months analyzed resulted in 231,411 cases, as shown below.

Considering the two map sequences (figures 01 and 02), it is possible to observe that the increase in registered cases occurs following the flow of the busiest highways, thus, if in January and February 2020, a considerable number of municipalities did not present a single case of Sars, in March almost all of them already registered some cases, and the sub-regional centers where the BR-101 highway and the metropolitan region of Rio de Janeiro can be found, already had an alarming number of occurrences.

Thus, municipalities that followed strict isolation measures were able to mitigate the impact of Covid-19 in their territories, which had adverse consequences in the municipalities that did not adopt such procedures. It should be noted that the most impacted municipalities were those from Grande Rio, whose daily work flows with the capital are intense, as can be seen on map 05, resulting, thus, in the death of thousands of citizens from Rio de Janeiro, only in the Metropolitan Region of Rio de Janeiro (RMRJ) (Map 5). 
Figure 1 - Spatial evolution of hospitalized SARS cases in the state of Rio de Janeiro, from January to June 2020
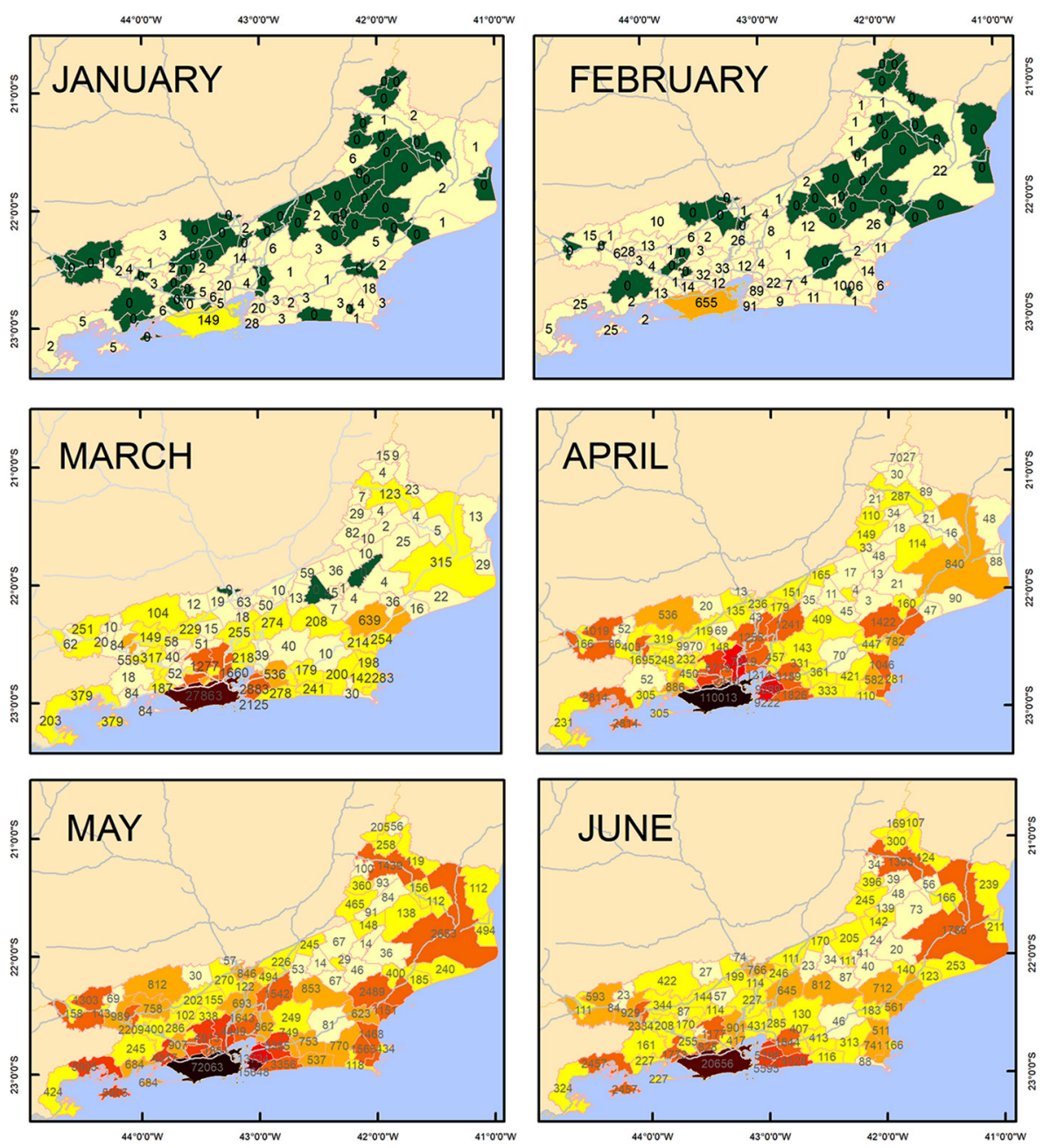

Monthly sum of Severe Acute Respiratory Syndrome cases,

who were hospitalized in the city of Rio de Janeiro (Municipality of origin)

$\begin{array}{lll}0 & 500-1000 & 7000-14000\end{array}$

$1-100$

$1000-3500$

$14000-35000$

$100-500$

$3500-7000$

$35000-231.411$

Federal Highways Municipal limits

States

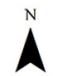

Source: IBGE, Ministério da Saúde DATUM SIRGAS 2000

Source: Datasus (2020), accessed on: 7/21/2020. Prepared by the authors. Cartographic base: IBGE (2020). 
Figure 2 - Spatial evolution of hospitalized SARS cases

State of Rio de Janeiro (sum of the months from January to June 2020)
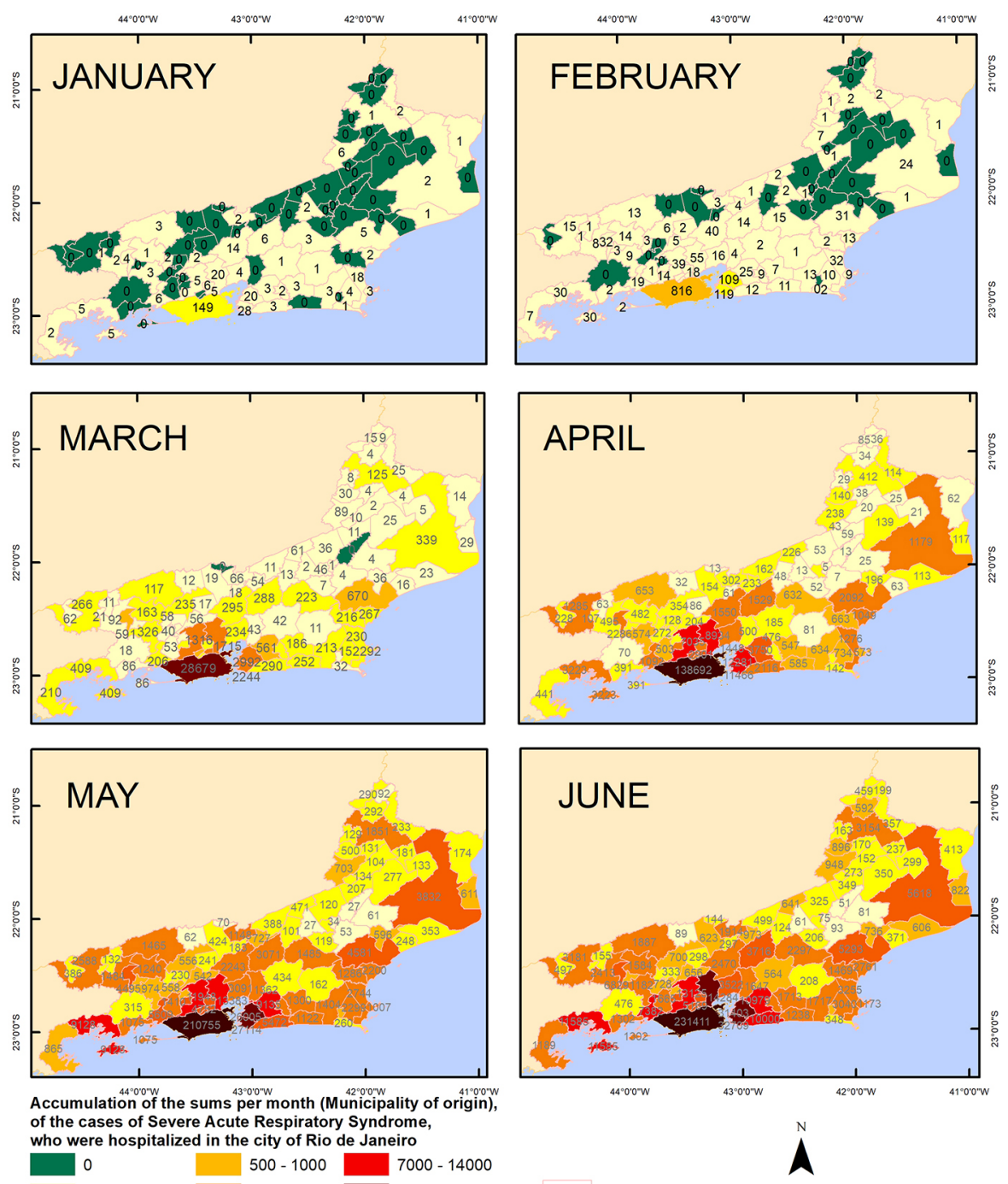
of the cases of Severe Acute Respiratory Syndrome,

\begin{tabular}{|l|l|l|l|}
\hline 0 & $500-1000$ & $7000-14000$ \\
$1-100$ & $1000-3500$ & $14000-35000$ \\
$100-500$ & $3500-7000$ & $35000-231.411$ \\
\hline
\end{tabular}

RM_RJ

States Source: IBGE, Ministério da Saúde
DATUM SIRGAS 2000

Source: Datasus (2020), accessed on: 07/21/2020. Prepared by the authors.

Cartographic Base: IBGE. 
Map 5 - Map of deaths by Covid-19 in the RMRJ and people from the RMRJ who work in the city of Rio de Janeiro - RMRJ, 8/8/2020
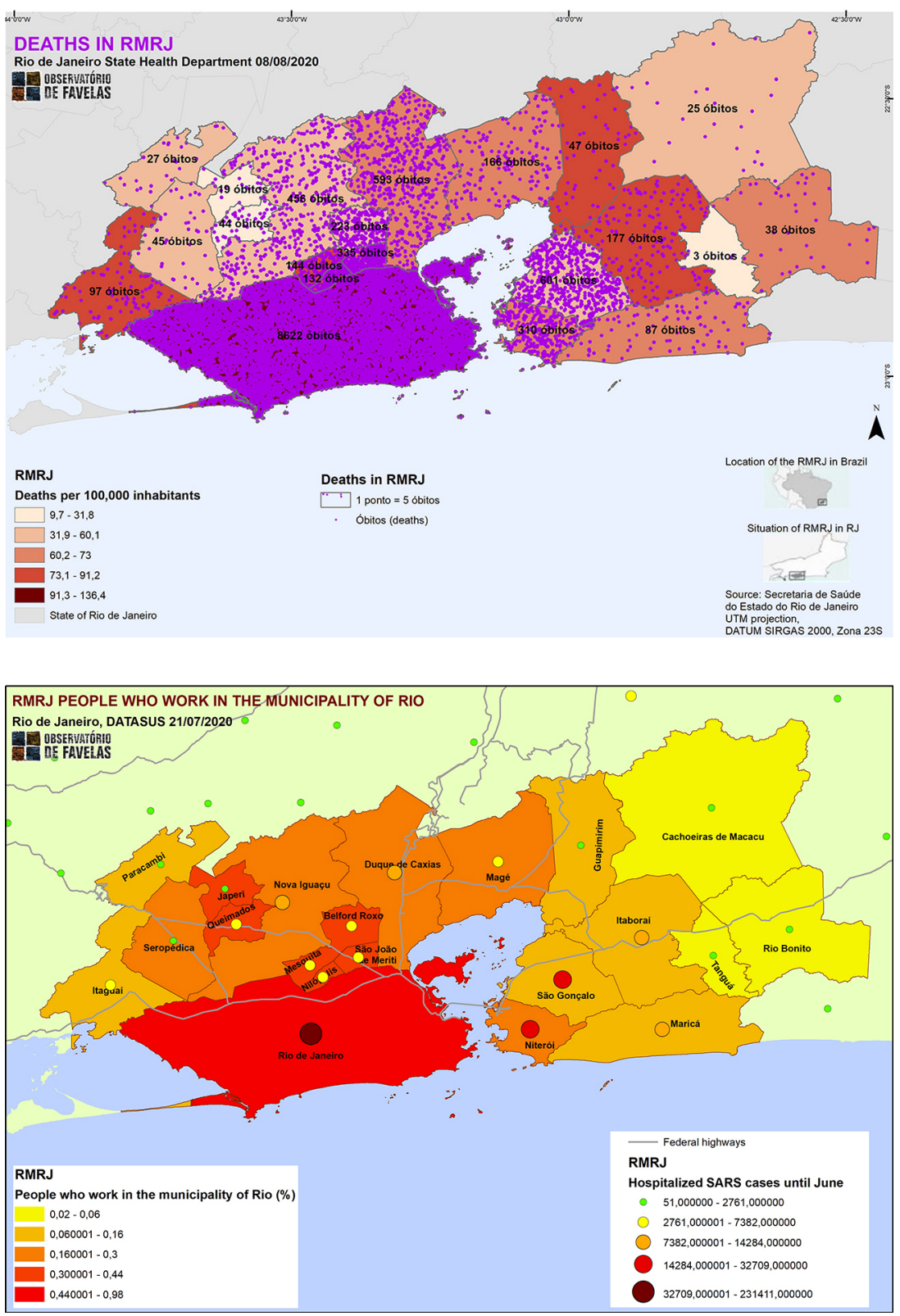

Source: Datasus (2020), acessed on: 8/8/2020. Prepared by authors. 
From the exhibitions regarding population flows related to work and also to the very position of the capital of Rio de Janeiro as a national metropolis, it was possible to point out a direct relationship between the dissemination of Covid-19 in the State of Rio de Janeiro and the impact on its capital, which caused a greater loss to the population with less purchasing power. The effect of the pandemic was not just more devastating, due to the mobilization of the population and solidarity actionsation of the population and solidarity actions.

\section{Final considerations}

The present article started from the thesis that the pandemic in Rio de Janeiro was imported by the wealthy having its dissemination process amplified over the months towards the peripheral areas of the city. Its basic premise that the peripheral population ended up being the most affected in the Covid-19 panorama was confirmed, but at the same time, countered by the antithesis that was established through the heroic performance of the professionals of the National Public Health System (SUS), and also because of local solidarity actions that contributed to mitigate the impact of the pandemic in the capital of Rio de Janeiro.

The analysis of the performance of sociospatial agents at different scales combined with cartographic resources allowed a partial view of some elements that contributed to the spread of the disease in the city, allowing important findings among which it is possible to highlight the following:
The wealthiest area of Rio de Janeiro located on AP 02 and South of AP 04 had a high rate of contagion but a low lethality rate in contrast to AP 03 and, especially, AP 05, which, having a large portion of more impoverished areas in its neighborhoods and a greater exposure to urban social vulnerabilities, ended up having a higher mortality rate. The low income areas presented a higher number of deaths than many wealthy neighborhoods in the municipality even when it presented a smaller amount of contaminated.

The overlap of the HDI with the lethality rate showed that the areas with the highest HDI had a reduced mortality rate, when compared to those with the lowest HDI. We also added a look at the spatialization of health equipment in the capital of Rio de Janeiro, observing patterns of centralization in its distribution and unequal conditions of access to health. The overloading of health equipment in the city of Rio de Janeiro and the distribution of equipment aimed at combating Covid-19 can also be demonstrated by the overload of care demands from across the state.

Expanding the scale of analysis, it was possible to observe through the map that the spatial spread of the virus in the territory of Rio de Janeiro was temporalized and its expansion followed the main road flows in the state, such as BR-101. It is worth mentioning that Covid-19 was imported from the airports to the national territory.

At the end, the present study, included in the analysis, researches and publications produced by social organizations and popular and public institutions, reveals the deepening of urban social inequalities. The city built on 
hierarchical structures in the distribution of opportunities and rights confirms its genesis in facing the pandemic.

However, this diagnostic finding does not define Rio de Janeiro entirely. We revere and point out, as possible horizon, the territories and popular inhabitants of the city which proliferated attitudes and demonstrations in defense of life. Both the actions of solidarity developed by organizations, leaders and residents of favelas and peripheries and the herculean work of public health professionals were crucial to avoid a bigger tragedy.

This article, far from having conclusive claims, indicates that, while a more effective medical treatment for Covid-19 is not discovered, the best measures to be taken should be those of a spatial character, such as social isolation. We bring here our contribution in mitigating the social impact of the pandemic in the face of the city's inequalities.

\section{[1] https://orcid.org/0000-0003-3483-4794}

Universidade Federal Fluminense, Instituto de Ciências da Sociedade e Desenvolvimento Regional, Programa de Pós-Graduação em Geografia. Campos dos Goytacazes, RJ/Brasil.

danalbrib@gmail.com

[II] https://orcid.org/0000-0003-3921-2775

Observatório de Favelas, Rio de Janeiro, RJ/Brasil.

aruan@observatoriodefavelas.org.br

[III] https://orcid.org/0000-0003-1980-5899

Observatório de Favelas, Rio de Janeiro, RJ/Brasil.

linotex7@gmail.com

Translation: this article was translated from Portuguese to English by the authors themselves. 


\section{Notes}

(1) A survey entitled Mapa Social do Corona carried out by a group of researchers from the Observatório de Favelas with 11 editions of published bulletins (OF, 2020). For each edition there were partnerships with researches from other institutions.

(2) The starting point of the article is in the municipality of Rio de Janeiro, however the analysis gravitates at different scales. Thus, in some moments, spatial analyzes took place on the urban scale of places, moving to the metropolitan, state and national scales.

(3) The reports obtained in the in-depth interviews can be found in the fifth edition of the Mapa Social do Corona (Barbosa et al., 2020) such as the interview with nurse Michele Galdino, resident doctor Roberta Fiovaranti, doctor Ernesto Faria Neto and resident doctor Maira Brandão.

(4) Volta Redonda, Macaé, Campos dos Goytacazes, Niterói and Maricá are examples of cities that, in addition to receiving patients from other municipalities, sometimes receive patients from the capital itself.

(5) The federal government should act with energetic, combined and intelligent isolation actions, thus gaining time to prepare actions to combat contagion. However, the declarations of the President of the Republic, weakening and deconstructing state and municipal attempts to contain the spread of the pandemic and minimizing the effects of the disease, were decisive for the country's catastrophe, culminating in another 100,000 deaths.

\section{References}

AÇÃo COVID 19 (2020). Índice de Proteção ao COVID 19 (IPC19). Disponível em: https://acaocovid19. org/publications/note3. Acesso em: jun 2020.

BAHIANA, L. C. C. (1978). Agentes modeladores e uso do solo urbano. ASSOCIAÇÃO DE GEÓGRAFOS BRASILEIROS. Anais... Rio de Janeiro, n. 18, pp. 53-62.

BARBOSA, J. L. et al. (2020). Acesso desigual à saúde no Rio de Janeiro. Adversidades sanitárias históricas e direitos urgentes à vida saudável. Disponível em: http://of.org.br/wp-content/ uploads/2020/07/Mapa-Social-do-Corona-05.pdf Acesso em: ago 2020.

CORRÊA, R. L. (2005). O espaço urbano. São Paulo, Ática.

(2013). "Sobre agentes sociais, escalas e produção do espaço: Um texto para discussão". In: CALOS, A. F. A.; SOUZA, M. L.; SPOSITO, M. E. B. A produção do espaço urbano: agentes e processos, escalas e desafios. São Paulo, Contexto.

DATASUS (2020a). SRAG 2020 - Banco de Dados de Síndrome Respiratória Aguda Grave - incluindo dados da COVID-19. Disponível em: https://opendatasus.saude.gov.br/dataset/bd-srag-2020 Acesso em: 21 jul 2020.

(2020b). Cadastro Nacional dos Estabelecimentos de Saúde. Disponível em: http:// estabelecimentos.datasus.gov.br/. Acesso em: jul 2020. 
FORM, W. H. (1954). The place of social structure in the determination of land use: Some implications for a theory of urban ecology. Social Forces. Michigan, v. 32, n. 4.

HARVEY, D. (2006). Espaços de esperança. São Paulo, Loyola.

IBGE (2008). Regiões de influência das cidades 2007. Rio de Janeiro. Disponível em: https://biblioteca. ibge.gov.br/visualizacao/livros/liv40677.pdf. Acesso em: jun 2020.

(2010). Censo 2010. Disponível em: https://censo2010.ibge.gov.br/. Acesso em: jun 2020.

IBGE (2020). Sistema IBGE de Recuperação Automática. Disponível em: https://sidra.ibge.gov.br/ home/pmc/brasil. Acesso em: jul 2020.

IPEA (2020). Estudo de oportunidade de acesso à saúde. Disponível em: https://www.ipea.gov.br/ acessooportunidades/. Acesso em: jul 2020.

IPP (2020). DATA.RIO. Informações sobre a cidade. Disponível em: https://www.data.rio/ Acesso em: ago 2020.

(2020). Painel Rio Covid 19. Disponível em: https://www.data.rio/app/painel-rio-covid-19. Acesso em: jun 2020.

OF - Observatório de Favelas (2020). Mapa social do corona. Rio de Janeiro, OF.

OPAS (2020). Folha informativa COVID-19. Escritório da OPAS e da OMS no Brasil. Disponível em: https://www.paho.org/pt/covid19. Acesso em: set 2020.

MORIN, E. (1995). Ciência com consciência. São Paulo, Companhia das Letras.

RIBEIRO, D. de A. (2018). Migrações para o Eixo Pelourinho Santo Antônio. Salvador - Bahia. Tese de doutorado. Salvador, Universidade Federal da Bahia.

SANTOS, M. (2003). Por uma outra globalização. Rio de Janeiro, Record.

(2008a). Economia espacial. Críticas e alternativas. São Paulo, Edusp.

(2008b). A natureza do espaço. São Paulo, Edusp.

VASCONCELOS, P. de A. (2006). "Os agentes modeladores das cidades brasileiras no período colonial". In: CASTRO, I. E.; GOMES, P. C. C.; CORRÊA, R. L. Explorações Geográficas. Rio de Janeiro, Bertrand Brasil.

(2013a). "Contribuição para o debate sobre os processos e formas socioespaciais nas cidades". In: VASCONCELOS, P. A.; CORREA, R. L.; PINTAUDY, S. M. (orgs.). A cidade contemporânea, segregação espacial. São Paulo, Contexto.

(2013b). "A utilização dos agentes sociais nos estudos de Geografia Urbana: Avanço ou recuo?". In: CALOS, A. F. A.; SOUZA, M. L.; SPOSITO, M. E. B. A produção do espaço urbano: agentes e processos, escalas e desafios. São Paulo, Contexto. 
